\title{
Waste and Global Warming
}

\author{
Anita Dewi Moelyaningrum \\ Department of Environmental Health and Occupational Health and Safety \\ Public Health Faculty University of Jember, East Java Indonesia. \\ anitamoelyani@gmail.com or anitadm@unej.ac.id
}

\begin{abstract}
Waste was produced by human activity. Open dumping is the most method applied in Indonesia's waste management system. Methane $(\mathrm{CH} 4)$ can produce from waste open dumping method. Methane is a dangerous greenhouses gas. Methane $(\mathrm{CH} 4)$ in the earth's atmosphere is an important greenhouse gas with a global warming potential. It can damage ozone 21 faster than carbon dioxide (CO2). Indonesia's population in 2009 was 234 million. Everybody produces waste of $800 \mathrm{gr}$ per day per person. The estimate Indonesia waste was 187,200-tons per day, which 1 ton of waste can produce $50 \mathrm{~kg}$ of methane $(\mathrm{CH} 4)$ gases. Global warming can reduce by a good waste management system. It can reduce some of the dangerous greenhouse gases such as methane $(\mathrm{CH} 4)$ and carbon dioxide $(\mathrm{CO} 2)$. Open dumping method must be stopped. The alternative to control the emission of methane $(\mathrm{CH} 4)$ is applied sanitary landfill method.
\end{abstract}

Keyword: waste, methane $(\mathrm{CH} 4)$, global warming 